\title{
Double-Voiced Discourse in Susan Glaspell's Trifles
}

\author{
Yulistiyanti $^{{ }^{*}}$ \\ Agnes Widyaningrum ${ }^{2}$ \\ Endang Yuliani Rahayu ${ }^{3}$ \\ Universitas Stikubank \\ Semarang, Indonesia. \\ *yulistiyanti@edu.unisbank.ac.id
}

Article History: Submitted on $30^{\text {th }}$ October 2020; Accepted on $17^{\text {th }}$ November 2020;

Published on $31^{\text {th }}$ December 2020

\begin{abstract}
This research reveals double-voiced discourse and ideologies found in dialogues of Susan Glaspell's Trifles. This research is categorized as a qualitative study. It does not need numbers to analyze the data. The data was taken from Glaspell's Trifles text by applying close-reading and identified by applying Bakhtin's double-voiced discourse (1981) and Baxter's double-voiced discourse functions (2014). It also applied Kate Millet's Sexual Politics (2000) and Putnam Tong's Feminist Thought (2009) to analyze the ideologies found in the text. There are thirteen double-voiced discourses found in Trifles. They represent two opposite ideologies; patriarchy and feminism delivered by the male and female characters. The discourses show three types of double-voiced discourse; personal power, debate ideas, and building solidarity. The male characters, Sheriff and County Attorney use the discourses to display personal power representing patriarchal ideology. Meanwhile, the female characters, Mrs. Hale and Mrs. Peters use the discourses to debate ideas and build their solidarity as women that show feminism as an ideology.
\end{abstract}

Keywords: double-voiced discourse, Susan Glaspell, Trifles, Bakhtin, Baxter 


\begin{abstract}
ABSTRAK
Penelitian ini mengungkap diskursus double-voiced dalam dialog drama berjudul Trifles karya Susan Glaspell. Penelitian ini termasuk penelitian kualitatif. Penelitian ini tidak. memerlukan data dalam bentuk angka. Data penelitian ini diambil dari teks drama Trifles karya Glaspell dengan menerapkan close-reading dan diidentifikasi dengan menerapkan diskursus double-voiced oleh Bakbtin (1981) dan fungsi dari diskursus double-voiced oleh Baxter (2014). Selain itu, penelitian ini juga menerapkan teori dari Kate Millet dalam Sexual Politics (2000) dan tulisan Putnam Tong dalam Feminist Thought (2009) untuk menganalisis ideologi yang ditemukan dalam teks. Penelitian ini menemukan tiga belas diskursus double-voiced dalam drama Trifles. Diskursusdiskursus tersebut menunjukkan dua ideologi yang berlawanan; patriarki dan feminisme yang disampaikan oleh karakter laki-laki dan perempuan. Diskursus-diskursus tersebut menunjukean kekuatan pribadi, diskusi, dan membangun solidaritas. Karakter laki-laki Trifle; Sheriff dan County Attorney menggunakan diskursus untuk. menampilkan kekuatan pribadi yang mewakili ideologi Patriarki. Sedangkan karakter perempuan; Nyonya Hale dan Nyonya Peters menggunakan diskursus untuk diskusi dan membangun solidaritas sesama perempuan yang menunjukkan ideologi feminisme.
\end{abstract}

Kata kunci: diskursus double-voiced, Susan Glaspell, Trifles, Bakbtin, Baxter

\title{
INTRODUCTION
}

Drama is a literary work that is written containing dialogues. The dialogues represent communication commonly used in daily conversation. The dialogues in a drama are presented by characters a playwright created. The characters also represent human beings' characteristics that can be revealed from the actions, behaviors, comments, and thoughts (Pfister, 1993).

The dialogues in a drama flow from one character to another character that transfer information. Delivering communication can contain two opposite principles, opinions, intentions, or meanings that the speaker realizes or not. The two opposite principles also contain in a statement that means there is no two-way communication. It happens in one-way communication that the speaker has aims such as entertaining, persuading, commanding, or informing something. Two opposite principles, opinions, intentions, or meanings in a dialogue indicate a double-voiced discourse. The discourse causes the readers to create the question or answer on the dialogue because there is one voice disguising in another one. Characters in drama bring their principle or ideology and the author's principle or ideology in the dialogues covered by another intention.

The two opposite principles, meanings, opinions, or intentions come out from communication. This kind of communication can be either oral or written. A speaker that applies an utterance containing two different 
or opposite principles is to anticipate, to mitigate, to correct, and to heighten impact and show personal power (Baxter, 2014). This kind of communication applies Bakhtin's notion, the double-voiced discourse. Baxter applies the notion of daily communication that occurs at work. With some functions of double-voiced discourse that Baxter revealed, this discourse is useful in cross-culture communication.

Cross-culture communication happens among people of different ethnicities, backgrounds, and nations. These differences cause problems among people to interact with. Cross-culture communication results in meaning and sense that the recipient understands or not, and it depends on word and phrase choice in the statement used by the speaker (Andreyeva, 2015).

Not only does communication cause different meanings, but different genders also may cause dual intentions. It happens from the relation between men and women in which men are superior while women are inferior (Baxter, 2011). Men and women have different functions and responsibilities in society. It is a part of calling in genders. The different positions of men and women in society create them to communicate differently (Ambarita \& Mulyadi, 2020). They use different vocabulary, intonation, and voice. They use them differently because society will stamp stigma for them if they do not do as suggested based on gender (Coates, 2013). For example, it is not appropriate for a woman to speak loudly. On the other hand, men must speak loudly.

Communication in different genders often put women as the second player. Although some proverbs state differently that women dominate the conversation or communication as foxes are all tails and women are all tongues. This proverb sounds denigrate women by comparing women and foxes. This kind of communication is found in a drama. Drama is a literary work that uses dialogues as the composition. One of the dramas that present men-women communication is Trifles by Susan Glaspell.

Susan Glaspell describes women and men's relationships in a drama entitled Trifles. It tells about a murder what Mrs. Wright did to her husband. The characters from both genders participate in investigating the murder. There are dichotomies between men and women. They come out from the areas they investigate, the way they speak, and how they respond to the case. From the dichotomies, double-voiced discourse takes the role that it shows two different intentions from utterances in the dialogues. The dialogues in the drama contain voices reflected in the characters' dialogues that represent two opposite ideologies; patriarchy and feminism.

Glaspell depicts that the female characters of Trifles live in a patriarchal society where makes them adopt the norms. She shows their roles in the family and their manners. Although the female characters adopt the norms, they disagree with what happens to how men treat women, especially how Mr. Wright treated his wife. There are some protests in their utterances and their actions toward what they experience. They do not state 
it directly in the dialogue. On the other hand, the male characters show their power in the utterances and actions.

Nodeh found Jane Austen's voices hidden in some utterances of the characters and the narrator of Emma. Austen applies Bakhtin's doublevoiced discourse in her novel, Emma. Austen expresses her repressed opinions as a woman living in a patriarchal society through the minor character of Emma, Miss Bates, and the narrator. The narrator delivers two opposite principles in the utterances; one side expresses femininity, and another side shows a monstrous female. Then, Miss Bates is depicted as a rebellious character toward male-domination. She rebels against the domination comically. It shows that Austen applies Bakhtin's double-voiced discourse in Emma to criticize the social condition (Nodeh, 2013). Nodeh examined how Austen applied double-voiced discourse in Emma, and it shows two different ideologies exposed. It only focuses on Miss Bates' utterance that shows Austen to protest toward the female social condition in the novel. Nodeh did not examine why the male characters use the utterances in Emma.

Maddison applied Bakhtin's double-voiced discourse in Toni Morrison's Beloved. He highlighted the allusion found in the novel. An allusion is one voice heard, but it is spoken in another language. The allusion creates dialogism for the readers. Some questions emerge from the allusion. Maddison limits the allusions found to the Bible and applied intertextuality in discussing the double-voiced discourse of allusion found in Morrison's Beloved. The different voices of the allusion are connected to the Bible (Maddison, 2007). By employing double-voiced discourse of allusion, Maddison still dialogized the function of the novel for African-Americans; whether the novel will be remembered or will be forgotten.

Discussing double-voiced discourse through literary works; novel, poetry, or drama can be known the functions of the utterances or dialogues used. This research examines double-voiced discourse, the ideologies, and the functions of it delivered by characters in the drama Trifles. This research is applied in drama text that represents verbal communication in life. The functions of the discourse can be applied in verbal communication.

Double-voiced Discourse (DvD) is a notion written by Mikhail Bakhtin (1981). He wrote his notion in his essay entitled Discourse in the Novel. This essay reveals languages used in literary work, especially novels. He states the language is from a real condition adopted from society in which people communicate. Language is leveled and contains multiple dialect and idiolect as an expressive system in the forms that carry the meaning. Then the language is adopted by the author in his/her work. There are some notions in the essay, one of them is double-voiced discourse.

Bakhtin defines double-voiced discourse as a discourse that serves two speakers at the same time and expresses two different intentions. The speakers are the character who is speaking in the literary work and the 
author who wrote the literary work. Each speaker has its own intention, the character delivers direct intention, and the author delivers intention refracted. This kind of discourse contains two voices, two intentions, and two meanings. Both voices are interrelated as if they communicate with each other (Bakhtin, 1981).

Bakhtin formulated a double-voiced discourse notion in literary work. Then, this notion develops. It is not only applied in literary work, but it is also applied in daily communication. Judith Baxter (Baxter, 2014) developed double-voiced discourse into five types based on the function. The five types of double-voiced discourse are as follows:

1. Anticipatory. It is to anticipate and dilute power.

2. Corrective. It is to correct or repair a mistake or error that is made by the speaker.

3. Mitigating. It is to mitigate the distance, reduce authority, and build solidarity with their team.

4. Authoritative. It is to heighten impact and display personal power, especially if it is threatened.

5. Dialogic. It is to debate ideas if the speaker is both the addresser and the addressee.

The five types of double-voiced discourse emerge when the speaker feels anxious about the responses of the interlocutor that the speaker predicts may threaten $\mathrm{him} /$ her.

\section{METHOD}

This study is classified as qualitative research that there is no numerical data needed (Kothari, 2004). It focuses on analyzing the doublevoiced discourse, the two opposite ideologies, and the functions of doublevoiced discourse in a drama text entitled Trifles written by Susan Glaspell. The data taken in this research are the dialogues of characters in the drama.

Conducting this research needs some procedures to conduct study. First, read the data by applying close reading and taking notes. In reading the text, it needs to find out the words meaning and interconnected words meaning in each dialogue. After reading the text and getting the meanings of the dialogues, it identified the dialogues based on Bakhtin's doublevoiced discourse. The identification results in 13 data categorized as doublevoiced discourses. After that, the researchers analyze the data by applying Bakhtin's double-voiced discourse, Kate Millet's Sexual Politics, Putnam Tong's Feminist Thought, and Baxter's types of double-voiced discourse. The analysis is divided into three steps. The first step analyzed the voices of each dialogue. The second step analyzed the ideologies by finding out the meaning of the dialogue relating to the two feminism theories. The third step analyzed the type of the discourse by regarding the meaning of the 
dialogue, actions written in the text, the speaker's and addressee's genders. Finally, they interpret the data.

\section{FINDINGS AND DISCUSSION}

\section{Double-Voiced Discourse in Susan Glaspell's Trifles}

Trifles written by Susan Glaspell is a one-act drama. It means the drama contains rising action, climax, and resolution in one part. From the beginning of the drama, readers can find exposition in which then delivers the story into raising action. Then, it goes to climax, and finally, it ends in resolution.

In this drama, dialogues spoken by the characters have monologic discourse and dialogic discourse. Some dialogues express clear statements of the characters, and some dialogues hide another intention or ideology of the characters. This research focuses on dialogic discourse in which the meaning of an utterance can be negotiable. The kind of discourse revealed is double-voiced discourse.

Glaspell's Trifles uses male and female characters in solving a homicide. When the sheriff and the attorney investigate the crime scene, they are also accompanied by Mr. Hale as the witness, Mrs. Peter, and Mrs. Hale. In the investigation, the dialogues expose double-voiced discourse in which a speaker speaks in two different ideologies. The characters of Glaspell's Trifles bring patriarchal and feminism ideologies. Most of the characters are dominated by patriarchal ideologies, especially the male characters. On the other hand, the female characters realize that they live in a male-dominated society in which makes them oppressed, then they want to defend their female neighbor by hiding the evidence.

Double-voiced discourse comes in Trifles from both the male and female characters. The discourse explores John Wright's murder caused by domestic problems. The domestic problem happens not only in Wright's family but also in the male-dominated society in general. The domestic problem here concerns a male and female relationship as a married couple. The problematic relationship goes into the domestic jobs of the female. Then, the dialogues in the investigation reveal female characteristics.

The researchers focus on the utterances of the male characters first in revealing double-voice discourse. After that, the discussion goes to the female characters' utterances. Both different genders have two different points of view in uttering the condition and situation in Glaspell's Trifles.

Double-voiced discourse in Trifles reveals some domestic life and domestic job as trivial things. Things that connect to domestic job and life are activities and things that happen in a house. Domestic is close to women area. The utterances spoken by the male characters tend to treat domestic things as minor or unimportant ones. The kitchen is one of the women's 
areas in a house where women spend most of their time here. The utterance of Sheriff about the kitchen ('Nothing here but kitchen things' (Glaspell, 2013)) contains double meanings. Kitchen things are considered not important things because it is the area of Mrs. Wright spending her time as a woman in general that is considered inferior. On the other hand, the Sheriff assumes it is impossible to find any evidence of the murder. County Attorney supports the Sheriff's opinion by stating what the female characters take for Mrs. Wright is not dangerous ('Oh, I guess they're not very dangerous things the ladies have picked out.' (Glaspell, 2013)) County Attorney utterance shows that female stuff such as apron, quilt, and scarf do not have signs that may help them find out the truth. Then, it can be supposed that the female stuff is the minor thing or the trivial thing that only relates to women's life. The voices of both utterances are refracted from the female playwright into the male characters' (Sherrif and County Attorney) dialogues.

Continuing discussing the kitchen and its stuff in it, double-voiced discourse is also found in County Attorney's utterances about the result of the activity in the kitchen. The food made and the tidiness of the area become spotlights for the characters in Trifles. Women will get stigma as good persons (successful ones) if they fulfill the characteristics men defined. One of the characteristics of good women is arranging the house well. Trifles reflects how men judge women's jobs in the house. Trifles uses a messy and gloomy kitchen as the setting. County Attorney speaks out that the kitchen is messy, then he adds that "I guess before we're through she may have something more serious than preserves to worry about" (Glaspell, 2013). Something serious in his utterance can be supposed that Mrs. Wright cannot arrange the house well or it can be meant there is a problem that causes her to get a problem. County Attorney's utterance shows the refraction of the female voice in the male voice.

Domestic job in the kitchen is the main job for the female in the male-dominated society. Females are responsible for tasks such as cleaning the kitchen towel and the table. County Attorney judges Mrs. Wright's work in the kitchen. He thinks that she does not do much better in housekeeping. The way he speaks needs agreement from the other female characters (Mrs. Peters and Mrs. Hale). His utterance is 'And yet, for all their worries, what would we do without the ladies?' (Glaspell, 2013). He tries to get sympathy from the females as if he cares about what females do. On the other hand, his voice disgraces the female job that they only do insignificant work. Their work is not hard, but the male works hard. His utterance tends to disgrace female work by saying 'Dirty towels!' (Glaspell, 2013) and he also kicks the pans. It is a refraction of the male-dominated society voice in County Attorney. Glaspell tries to show what the male-dominated society reacts to the condition. 'Not much of a housekeeper, would you say, ladies?' (Glaspell, 2013) is the next utterance that he wants the female to agree to 
what he said. It contains the way to blame Mrs. Wright as a wife who cannot be able to do her responsibility.

The female characters of Trifles state their opinions through the dialogues appointing their gender and their conditions. Susan Glaspell refracts her voices as a female in the two female characters, Mrs. Peters and Mrs. Hale. Double-voiced discourses are found in some dialogues of them. The voices depict the female condition in the male-dominated society in which they also want to define themselves as human beings.

Responding to the male characters on judging the female domestic job, the female characters sound to defense their gender in front of the male characters. Mrs. Hale responds to County Attorney that Mrs. Wright does not do much housekeeping by stating that 'Those towels get dirt awful quick. Men's hands aren't always as clean as they might be' (Glaspell, 2013). Her utterance defenses Mrs. Wright that is degraded by the Attorney. The voice comes from the playwright (female) refracted in Mrs. Hale's utterance. 'The towels get dirt' results from men's hands. They are not dirty by themselves. There is a cause of it. She wants to say 'do not blame women, if the work is not always as the men want'.

The male-dominated society puts men to control every field. It goes further when men interfere with domestic chores. One of the female dialogues comes from Mrs. Hale that 'I hate to have men coming into my kitchen, snooping around and criticising' (Glaspell, 2013). It is one of the double-voiced discourses in Trifles that a female character speaks. This dialogue contains double voices; the male-dominated side and feminism. The male-dominated voice emerges from the society that the female character agrees that the female works in the kitchen as a domestic area. On the other hand, the playwright inserts her voice in Mrs. Hale's dialogue to show her hatred for what men do. Being snooped around and criticized for what she does in the kitchen makes her inconvenient.

Mrs. Hale feels inconvenient to what men judge on the house condition. It makes her worried when the men go upstairs to find the evidence. Mrs. Hale's dialogue contains double voices that are 'Wonder how they are finding things upstairs. I hope she had it a little more red-up up there. You know, it seems of sneaking. Locking her up in town and then coming out here and trying to get her own house to turn against her!' (Glaspell, 2013). Mrs. Hale's dialogue reflects her worry about the messy house condition. She knows what men will say if they found messy upstairs rooms. This voice is refracted from the male-dominated society. But, she does not want Mrs. Wright to be degraded in this way. It is her way to defend Mrs. Wright from men's criticisms. This voice comes from the playwright into Mrs. Hale.

The Wright's house looks gloomy, and it causes Mrs. Hale not to come over it. It is reflected in 'I could've come. I stayed away because it weren't cheerful - and that's why I ought to have come - I've never liked this place. Maybe because it's down in a hollow and you don't see the road. 
I dunno what it is, but it's a lonesome place and always was. I wish I had come over to see Minnie Foster sometimes. I can see now -' (Glaspell, 2013). The utterance shows Mrs. Hale's regret and her support for maledominated society. Her regret supports feminism that comes from the playwright's voice. Looking at the house gloomy makes her stay away, it is the effect of male-dominated stigma. Women should be able to arrange and make the house tidy and well. She did not know the cause of the gloomy house condition. Gloomy house not only reflects the incapability of the wife but also reflects the desperate housewife. They are two opposite points of view.

The two opposite voices reflect the inconvenience of Mrs. Hale concerning Mrs. Wright. The following is Mrs. Hale's utterance that 'Not having children makes less work - but it make a quiet house, and Wright out to work all day, and no company when he did come in. Did you know John Wright, Mrs. Peters?' (Glaspell, 2013) shows her two opposite opinions. 'Not having children makes less work' implies that women's jobs are hard. It is better not to have children that women will have less burden. This voice comes from the playwright into Mrs. Hale. But, there will be a consequence of it in the male-dominated society. It is reflected in 'but it make a quiet house'. Women will only stay at home, while men work outside. It is a job division in society.

Another female character responds to Mrs. Hale's utterance on women's domestic condition, especially about children. Mrs. Peters has experience of how a woman does not have children. She said 'I know what stillness is. When we homesteaded in Dakota, and my first baby died - after he was two years old, and me with no other then -' (Glaspell, 2013). She agrees with Mrs. Hale that the voice comes from women in the maledominated society. And her utterance 'I know what stillness is' reflects that Mrs. Peters does not want Mrs. Wright to experience as she did. She is disappointed with the condition. This voice is the playwright's in Mrs. Peters'. She got the impact of losing a baby.

Double-voiced discourse is found in the following dialogue by Mrs. Hale; 'I wish you'd seen Minnie Foster when she wore a white dress with blue ribbons and stood up there in the choir and sang...Oh, I wish I'd come over here once in a while! That was a crime! That was a crime! Who's going to punish that?' (Glaspell, 2013). Mrs. Hale speaks about Minnie Foster (Mrs. Wright) appearance that symbolizes her freedom when she was single. It looks she can express what she wants and likes. Minnie Foster's appearance is not only meant how she dressed, but it expresses her freedom that women in the male-dominated society cannot reach. Freedom changed after she got married to John Wright. Glaspell sounds her opinion through Mrs. Hale that what happened to Minnie Foster is also a crime. It happens in society. Most women change, and it destroys their condition. To Minnie Foster, it changes into a disaster. The condition turns her to be a murderer. Society does not care about the cause. It focuses on the end; the husband 
died because of being strangled. Through Mrs. Hale, Glaspell wants to say that it is not fair for women.

Discussing the appearance of women, Mrs. Wright needs to wear an apron in jail. Mrs. Peters comments on what Mrs. Wright wants as follows; 'She said she wanted an apron. Funny thing to want, for there isn't much to get you dirty in jail, goodness knows. But I suppose just to make her feel more natural...' (Glaspell, 2013). The dialogue contains two opposite points of view. Wearing an apron represents inferiority and it does not need to show it in jail when the woman will not be controlled by the man (the husband). Glaspell, through Mrs. Peters, wants to say that it is the time to release the burden although she has to stay in the jail by saying 'funny thing to want'. Mrs. Peters dialogue also contains her curiosity about what she wants to know because it is on the contrary to when she was single. Then, Mrs. Peters convinces herself that her reason for wearing an apron is to feel natural. Feeling natural can be meant either that it is the way of Mrs. Wright to defend herself to be not guilty in front of the society or inferiority has stolen her freedom.

Mrs. Hale sympathizes with Mrs. Wright's condition after she and Mrs. Peters found a dead canary in a box. Her sympathy also reflects double-voiced discourse as follows;

' I might have known she needed help! I know how things can be for women. I tell you, it's queer, Mrs. Peters. We live close together and we live far apart. We all go through the same things - it's all just a different kind of the same thing, (brushes her eyes, noticing the bottle of fruit, reaches out for it) If I was you, I wouldn't tell her her fruit was gone. Tell her it ain't. Tell her it's all right. Take this in to prove it to her. She - she may never know whether it was broke or not.' (Glaspell, 2013).

Mrs. Hale realizes the condition that they live in a male-dominated society. What Mrs. Wright experienced is also experienced by other women in society. This voice comes from a patriarchal society that Mrs. Hale cannot refuse it. Then the rest of the dialogue shows that if they come together, they can pass it. This dialogue is also negotiable that they pass through the hard life together or they try to change the life condition.

Double-voiced discourse is found in the following dialogue by Mrs. Peters; 'My, it's a good thing that men couldn't hear us. Wouldn't they just laugh! Getting all stirred up over a little thing like - a dead canary. As if that could have anything to do with - with - wouldn't they laugh!' (Glaspell, 2013). This dialogue contains two voices; the female characters disclose the evidence to save Mrs. Wright, and the female characters succeed in finding the evidence. The dead canary is the evidence of John Wright's murder. The motive is Mrs. Wright's anger because John Wright strangled her canary. The female characters succeed in solving the mystery. On the other hand, if they show the evidence, the men will take it and bring it to the court to punish Mrs. Wright. 


\section{Patriarchy-Feminism Ideologies Reflected in Susan Glaspell's Trifles}

A literary work can be a medium for the contestation of ideologies. Two opposite ideologies show their roles at the same time. The readers will not find the winner in it. The work is only the arena of two ideologies or more displaying what they have.

One literary work that reflects ideological contestation is Susan Glaspell's Trifles. Trifles is a drama that displays patriarchy and feminism ideologies in the dialogues of the characters. Some points of the drama relate to the male-female relationship in society. They are job division and domestication.

Trifles tells about John Wright's murder which his own wife did it. The murder is the effect of the burden which she has held for years after she married him. The burden can be categorized as the oppression that not only Mrs. Wright experiences but also all women, especially Mrs. Hale and Mrs. Peters of this drama, as Mrs. Hale states that 'I might have known she needed help! I know how things can be - for women. I tell you, it's queer, Mrs. Peters. We live close together and we live far apart. We all go through the same things - it's all just a different kind of the same thing' (Glaspell, 2013). The setting of this drama is in the male-dominated society or patriarchal society where puts men in a dominant position. The dominant position creates some effect on the whole field.

One of the effects of male domination is job division. Patriarchy does not allow women to be outside of the house. So, women only have the right to work in houses or called domestic areas (Millett, 2000). Then, men have the opportunity to do outside of the house called the public area. This condition is reflected in Trifles that all female characters get burden in domestic chores. Moreover, Glaspell describes by showing what Mrs. Wright wants in jail is wearing an apron. The apron is a symbol for women who do domestic chores such as cooking and cleaning. On the other hand, the male characters have the opportunity to go outside of the house to sell the harvest to the town. Besides that, the area of investigation implicitly depicts the job division. The female characters investigate the kitchen and rooms in the house. But, the male characters go around the inside of the house and the outside of it.

The masculine authority takes female liberty. They become inferior and subordinated. It can be seen that women cannot decide what they want and define themselves (Tong, 2009). This condition happens in Glaspell's Trifles when Minnie Foster found her canary dead. She also does not wear a beautiful dress and does not sing in a choir. It is her freedom, especially when she was single. Marriage takes her freedom. Singing and listening canary to sing are her hobbies and to entertain herself, but she cannot do it after she got married to John Wright. It shows lacking liberty of Minnie Foster. This makes Mrs. Hale sympathetic to her. 
Another problem revealed in Trifles relates to women's feminity. Women should take care of their children. It is one of her responsibility besides doing domestic service ((Millett, 2000), (Tong, 2009)). The Wright family is described as having no children. It causes two different opinions. One considers that it is easy for women not to have children because they do not have more tasks in the house. Another looks at the impact of having no children from the male-dominated society. Unless these women get lonely, they can stay at home with the children while the men work outside. Moreover, women will get a bad stigma if they do not have children. Mrs. Wright and Mrs. Peters experience it. Mrs. Peters knows how she passed her life when she lost her baby. She is not only left by the baby but also other people around her.

Glaspell's Trifles portrays feminine and masculine characteristics on the way to investigate the murder. Glaspell shows the dichotomy between them on rationality and intuitiveness. Patriarchy defines the characteristics of both genders that cause a bad impact on both of them (Tong, 2009). The male characters are considered better than the female ones. The males think that they use their logical thinking to solve the mystery by observing the crime scene and the things Wright has. The males also underestimate the females on finding the evidence. They mock what the females found are not dangerous. But, this drama wants to show that female also has logical thinking to solve the mystery. They found the motive of the murder that is the anger of Mrs. Wright and also the evidence, the dead canary in a box.

Susan Glaspell succeeds in showing the effect of masculine authority through this drama. She shows that masculine authority may fight back against the males themselves. The oppression toward his wife causes John Wright's murder. The wife did it to relieve her burden because she has already been in a culminated position.

\section{The Functions of Double-Voiced Discourse in Susan Glaspell's Trifles}

The researchers found thirteen double-voiced discourses in dialogues of Susan Glaspell's Trifles. Baxter suggested that there are five functions of double-voiced discourse. They are used to anticipate, to correct, to mitigate, to heighten and to display personal power, and to debate ideas.

The first discourse comes from the Sheriff, "Nothing here but kitchen things' (Glaspell, 2013). It is classified to display his power as a man. The sheriff considers that the kitchen and the things cannot be evidence of the murder. They are only trivial things that women use.

The second discourse is delivered by County Attorney, 'And yet, for all their worries, what would we do without the ladies?...Dirty towels!....Not much of a housekeeper, would you say, ladies?' (Glaspell, 2013). He judges the kitchen condition that represents Mrs. Wright's 
incapability in arranging the house. This dialogue functions to heighten and display his power as a man.

The third discourse is found in Mrs. Hale's dialogue, 'Those towels get dirt awful quick. Men's hands aren't always as clean as they might be.' (Glaspell, 2013). She responds to what County Attorney judges to the Wright's kitchen condition. This discourse is categorized to build her solidarity as a woman to counter County Attorney's judgment. She gives a different point of view on the cause of the mess in the kitchen. Her utterance is so clear defending her gender. It is responded by County Attorney that calls Mrs. Hale is loyal to her gender.

The fourth discourse is found in Mrs. Hale's dialogue, 'I hate to have men coming into my kitchen, snooping around and criticising.'(Glaspell, 2013). She speaks to herself and her female friend that experiences a similar thing. She expresses her hate for males in front of her female friend. There are two different things in her utterance that makes debate. On one side, she does the work. Another side, she hates being criticized by the male without stating in front of the males. This discourse functions to debate the idea which the addressee and the addresser are Mrs. Hale and Mrs. Peters.

The fifth discourse stated by Mrs. Peters is, 'She said she wanted an apron. Funny thing to want, for there isn't much to get you dirty in jail, goodness knows. But I suppose just to make her feel more natural. She said they was in the top drawer in this cupboard. Yes, here. And then her little shawl that always hung behind the door...Yes, here it is.' (Glaspell, 2013). She wants to know why Mrs. Wright wears an apron in jail. It is categorized to debate the ideas of wearing an apron in jail. She does not need to confirm the answer. Talking to herself and thinking curiously are the ways to have a dialog with herself.

The sixth discourse stated by Mrs. Hale is, 'Well, I don't see any signs of anger around here, ...It's wiped to here, ...Wonder how they are finding things upstairs. I hope she had it a little more red-up up there. You know, it seems of sneaking. Locking her up in town and then coming out here and trying to get her own house to turn against her!'(Glaspell, 2013). It functions to debate the ideas. She wants to know what the male characters think and talk about the room condition. But, she does not ask the males. She speaks herself in front of Mrs. Peters. Worrying men judging the room condition makes her debate it.

The seventh discourse is in Mrs. Hale's dialogue, 'I could've come. I stayed away because it weren't cheerful - and that's why I ought to have come - I've never liked this place. Maybe because it's down in a hollow and you don't see the road. I dunno what it is, but it's a lonesome place and always was. I wish I had come over to see Minnie Foster sometimes. I can see now -' (Glaspell, 2013). She regrets what she did. She never came over to the Wright family. It is a soliloquy that she speaks herself. The addressee 
and the speaker are Mrs. Hale herself. She does not need to get responses from others and does not get it.

The eighth discourse delivered by Mrs. Hale is, 'Not having children makes less work - but it make a quiet house, and Wright out to work all day, and no company when he did come in. Did you know John Wright, Mrs. Peters?' (Glaspell, 2013). She debates on domestic service and child nurture. Both of them are female responsibilities. If a female chooses only one, there are consequences of lacking it. Mrs. Hale's dialogue is categorized to debate her ideas on domestic chores.

The ninth discourse is stated by Mrs. Peters. She responds to what Mrs. Hale states about the dead canary. The dead canary symbolized Mrs. Wright's stillness (Glaspell, 2013). It functions to build her solidarity as a woman on feeling stillness. Mrs. Peters remembers when she was in Dakota and lost her baby. She felt lonely. She discusses and speaks with herself because the addressee talks about different ideas.

The tenth discourse stated by Mrs. Hale is, 'I wish you'd seen Minnie Foster when she wore a white dress with blue ribbons and stood up there in the choir and sang... Oh, I wish I'd come over here once in a while! That was a crime! That was a crime! Who's going to punish that?' (Glaspell, 2013). Mrs. Hale expresses her anger and unfairness toward what Mrs. Wright experienced. Her anger functions to debate herself because she does not speak in front of the male characters that represent the male-dominated society. Society is too powerful to defeat.

The eleventh discourse again stated by Mrs. Hale to Mrs. Peters is, 'I might have known she needed help! I know how things can be - for women. I tell you, it's queer, Mrs. Peters. We live close together and we live far apart. We all go through the same things - it's all just a different kind of the same thing... If I was you, I wouldn't tell her her fruit was gone. Tell her it ain't. Tell her it's all right. Take this in to prove it to her. She - she may never know whether it was broke or not' (Glaspell, 2013). She thinks that every woman experiences the same thing that means burdens caused by male authority. The discussion happens between the female characters. She shares her solidarity with what happened to all women. This double-voiced discourse is categorized to build solidarity as women about women's burdensome.

The twelfth discourse delivered by Mrs. Peters wonders about finding a dead canary. Her dialogue contains worried when the male characters find the dead canary. Then they will laugh at it (Glaspell, 2013). This utterance functions to debate her curiosity about the dead canary.

The thirteenth discourse is spoken by County Attorney. He comments on what the female characters get in the kitchen. His discourse sounds powerful, and he has the authority to decide whether it is important or not important. The double-voice discourse here uses the phrase 'I guess'. Then it is followed by instruction '...they're not very dangerous things the ladies have picked out... No, Mrs. Peters doesn't need supervising. For that 
matter, a sheriffs wife is married to the law. Ever think of it that way, Mrs. Peters?' (Glaspell, 2013).

\section{CONCLUSION}

The result of the research presents three points relating to doublevoiced discourse found in drama entitled Trifles written by Susan Glaspell. After conducting the procedures of the research, the researchers found thirteen dialogues that represent double-voiced discourses. The four characters state the dialogues that appoint double-voiced discourse. The characters stating the discourses are two male characters (County Attorney and the Sheriff) and two female characters (Mrs. Peters and Mrs. Hale).

Double-voiced discourses in Susan Glaspell's Trifles show two opposite ideologies; patriarchy and feminism. The male character's discourses represent patriarchal ideologies. The female characters' discourses are dominated by patriarchal ideology and try to show their defense toward their gender that shows feminism ideology. Patriarchal norms influence their discourses to respond to the problem in men and women relation. The discourses are found in job division and gender characteristics.

The functions of the double-voiced discourses in Trifles are to display personal power, to debate ideas, and to build solidarity. The male character discourses use the function to display personal power. The discourses show his authority as an attorney and a man that thinks more superior than women. The female characters facing the conflicts in the text use discourses to debate their ideas and build solidarity as women.

This research may contribute to society to anticipate conflicts, anxiety, fear, and to build power in verbal communication by applying double-voiced discourse.

\section{REFERENCES}

Ambarita, R., \& Mulyadi. (2020). Gender and Language Politeness. European Journal of Applied Linguistics Studies, 2(2), 19-29. https://doi.org/10.5281/zenodo.3227254

Andreyeva, O. A. (2015). Cross-cultural Communication as a Way of Achievement of Cross-cultural Communicative Competence. European Researcher, 92(3), 208-213. https://doi.org/10.13187/er.2015.92.208

Bakhtin, M. . (1981). Mikhail-Bakhtin-The-Dialogic-Imagination-Excerpt.pdf (p. 2759). p. 2759.

Baxter, J. (2011). Survival or success? a critical exploration of the use of "double-voiced discourse" by women business leaders in the UK. Discourse and Communication, 5(3), 231-245. https://doi.org/10.1177/1750481311405590

Baxter, J. (2014). Double-voicing at Work. In Double-voicing at Work. 
Coates, J. (2013). Women, Men and Language (3rd ed.). New York: Routledge.

Glaspell, S. (2013). Trifles. 1-9.

Kothari, C. R. (2004). Research Methodology: Methods and Techniques (second revised edition) (Second Rev). New Delhi: New Age International (P) Limited.

Maddison, B. (2007). Liberation story or apocalypse? The Bible and Critical Theory, 3(2), 21.1-21.13. https://doi.org/10.2104/bc070021

Millett, K. (2000). Kate millett sexual politics. Feminist Literary Criticism, pp. 135-170. https://doi.org/10.4324/9781315846163

Nodeh, S. (2013). Dialogic Narrative Discourse in Austen's Emma: A Bakhtinian Review. K@Ta, 15(1), 1-7. https://doi.org/10.9744/kata.15.1.1-8

Pfister, M. (1993). The Theory and Analysis of Drama (U. Broich, H. Grabes, \& D. Mehl, Eds.). New York: Cambridge University Press.

Tong, R. (2009). Feminist Thought A More Comprehensive Introduction. Colorado: Westview Press. 